\title{
LESSONS FROM FISCAL DECENTRALIZATION IN UKRAINE
}

\author{
VARNALII ZAKHARII \\ Doctor of Economic Sciences, Professor \\ Taras Shevchenko National University of Kyiv, Ukraine, \\ Honored Worker of Science and Technology of Ukraine, \\ Academician of the Academy of Economic Sciences of Ukraine \\ vzs1955@gmail.com
}

\section{DEMYDENKO LIUDMYLA}

PhD in Economics, Associate Professor, Taras Shevchenko National University of Kyiv, Ukraine ipr.demydenko@gmail.com

\section{NAKONECHNA YULIIA}

PhD in Economics, Associate Professor, Taras Shevchenko National University of Kyiv, Ukraine tematika@ukr.net

\section{MIEDVIEDKOVA NATALIIA}

PhD in Economics, Assistant

Taras Shevchenko National University of Kyiv, Ukraine

nsmedvedkova@gmail.com

KEYWORDS: FISCAL DECENTRALIZATION, LOCAL BUDGETS, AMALGAMATED TERRITORIAL COMMUNITY, LOCAL GOVERNMENTS.

For citation: Varnalii Z., Demydenko L., Nakonechna Y., Miedviedkova N. (2019), Lessons From Fiscal Decentralization In Ukraine, Globalization And Business, №7, pp. 73-78. https://doi.org/10.35945/gb.2019.07.009

One of the most sensitive reforms for Ukrainian citizens is fiscal decentralization reform. The results of the activities carried out in this area were the growth of local budgets by 3.4 times over the period 2014-2018 (from UAH 68.6 billion to UAH 231 billion) (Monitoring of the process of decentralization, 2019). The monitoring of the process of decentralization of power and the reform of local selfgovernment as of February 10, 2019 emphasizes that it was created 838 amalgamated territorial communities (hereinafter ATCs), covering 9 million citizens for the period 2015-2018 (Reporting of the State Treasury Service of Ukraine, 2019). Nevertheless, according to international experts, this reform is one of the most successful in Ukraine, many issues remain unresolved.
The object of this study is the process of fiscal decentralization in the context of amalgamated territorial communities.

The subject istheoretical and practical approaches to analysis of reforms in budgeting amalgamated territorial communities and ensuring their transparency under fiscal decentralization in Ukraine.

Theoretical and methodological basis of research isto analyze necessity of fiscal decentralization reform in the context of amalgamated territorial communities and explore advantages and disadvantages of steps provided by the government in this direction; assess the state of transparency of amalgamated territorial communities under fiscal decentralization in Ukraine. 
Statistical analysis - Different statistical data, obtained from an electronic service Open Budget and Monitoring of the process of decentralization of power and the reform of local self-government have been analyzed. The information obtained from the Ministry of Finance of Ukraine,the State Treasury Service of Ukraine, the Ministry of Economic Development and Trade of Ukraine, the Ministry of Regional Development, Building and Housing and Communal Services of Ukraine was analyzed, as well as the dynamics of amendments to Budget and Tax Codes of Ukraine were researched.

The analysis of the official documentation - included the analysis and classification of the official data, documentation, decisions provided by the state departments.

The research is based on the Ukrainian works, the researches carried out and reports prepared by Ukrainian organizations, the official documentation of the state departments, various governmental and legislation documents (Concept of the Reform of Local Self-Government and Territorial Organization of Government, Budget and Tax Codes of Ukraine, laws such as "On Voluntary Association of Territorial Communities", "About the State Budget of Ukraine for 2019", "On Cooperation of Territorial Communities", "On Local Self-Government); as well as the interviews and surveys of the business entities.

The reform of structure of tax revenues of local budgets took place in 2015. It found its legislative recognition in Budget and Tax Codes of Ukraine. Thus, the government introduced tax incentives for the voluntary amalgamation of territorial communities. Such communities began to receive $60 \%$ of personal income taxes paid on territories of communities. Moreover, an additional local retail excise tax on sale of alcoholic beverages and petroleum products was implemented. Regional budgets received $10 \%$ of tax on corporate profits for the first time. Thus, the financial autonomy of local governments began to grow. This trend is continuing in 2019: personal income taxes on lease of land plots to individuals or shares by a tax agent, as well as $5 \%$ of rent on mineral extraction of national significance are charged in addition to local budgets; $13.44 \%$ of excise tax on fuel to local budgets is retained (The Budget Code of Ukraine, 2019; The Tax Code of Ukraine, 2019).

The transfer of significant funds to the local level exacerbates the problem of control over the targeted and efficient use of financial resources. In this context, it is important to comply with the requirements of the Law of Ukraine "About openness of the use of public means» (The Law of Ukraine on September 30, 2015), which requires the publication of information about size and direction of budget spending.

The Ministry of Regional Development, Building and Housing and Communal Services of Ukraine works quite successfully in this context: it accumulates and highlights information on rating of regions in the process of forming
ATCs and publishes monitoring monthly. According to the method of assessing the success of the process, a set of indicators has been determined: the number of ATCs that have amalgamated in the region; coverage of the region by ATCs; amounts of the population of ATCs. In addition, an electronic service Open Budget was created on the portal of the Ministry of Finance of Ukraine and implemented in November 2018 (Open Budget, 2018). It contains open data on tax revenues, transfers of local budgets and directions for spending funds.

The authors analyzed the level of openness of data on the finance of ATC on the availability of information of the following parameters: program of the socio-economic development; draft budget for the current year; public budget (a simplified form of visualization of revenues and expenditures of budget of ATC), minutes of public hearings on the budget; adopted annual budget, annual budget performance report; quarterly budget execution reports, debt policy document; information about borrowing and repaying; information on the status of implementation of investment projects that are being implemented; reports on implementation of budget passports.

Today we can note the insufficient level of disclosure of information on key financial indicators. It has been possible to create only official sites at the level of amalgamated territorial communities that contain a limited amount of information. It means that the sites of most ATCs disclosure only certain documents, and the share of ATCS that have complete information does not exceed $10 \%$. We can state the deep differentiation regarding the publication of information created on the sites of ATC and the importance of coordinating these processes by central authorities in organizing systematic work on ensuring transparency of local budgets.

The Government of Ukraine approved the Concept of the Reform of Local Self-Government and Territorial Organization of Government in April 2014 (Cabinet of Ministers of Ukraine, 2014). The purpose of this document is to change the outdated administrative-territorial structure of the country, inherited from times of the Soviet Union. By the beginning of the reform, the number of territorial communities was about 12 thousand; it means that the average size of the community was significantly less than 5 thousand people. The small average size of territorial communities led to the subsidization of most of them. Therefore, the amalgamation of territorial units was chosen as one of the most important directions of the decentralization policy in Ukraine. The Law of Ukraine "On Voluntary Association of Territorial Communities" created legislative grounds for the consolidation of territorial units. As of February 2019, 878 ATCs were formed and united 4,018 local councils; more than 9 million citizens live in them nowadays (Verkhovna Rada of Ukraine, 2015). The unification process is planned to be completed by the end of 2020. To create a favorable environment for the unification of communities, the Government also allocated funds to 
financially support the development of the infrastructure of the ATCS (UAH 1.94 billion in 2018). It should also be noted that UAH 2.1 billion are provided for the subvention for formation of the infrastructure of ATCs in 2019 (About the State Budget of Ukraine, 2019).

The Law of Ukraine "On Cooperation of Territorial Communities» has created a mechanism for solving general problems of ATCs - garbage collection and processing, the creation of a common infrastructure, etc. As of February 2019, 1262 ATCs used the mechanisms proposed by this law by signing 325 agreements on co-operation.

In parallel with the amalgamation of communities, some changes in their budgets have been made. ATCs have received additional sources of income and new powers to meet the needs of the local population, which allows them to effectively manage local economic processes.

Budget decentralization is the transfer of significant powers and financial resources from state authorities to local self-government bodies, the transfer of new voluntarily amalgamated territorial communities in Ukraine to direct intergovernmental relations with the state budget. The main results of the reform of fiscal decentralization should be the following: improving the quality and accessibility of public services, creating safe and comfortable environment for human life, participation of public in solving local issues.

Fiscal decentralization is the denationalization of power, the expansion of the source base, the transfer of responsibility, rights and resources to the local level. It is accompanied by a complete transformation of the budget system in the process of creating amalgamated territorial communities in Ukraine. The main goal of the budget decentralization reform is to increase the well-being of all members of the territorial community, improve the quality of public services at the local level and reduce the level of corruption and distrust in local authorities.

The main objectives of the reform are to strengthen the legal, organizational and financial viability of the amalgamated territorial communities, to improve the motivation in increase of the revenue base of their budgets. But it is impossible without comprehensive steps in the conduct of decentralization in such areas as: education in rural areas, health care, land relations, provision of administrative services, architectural and construction control (Fig. 1).

Effective changes in these industries are based, on the one hand, on further transfer of large powers to local governments, as such power structures which are closer to people and they know educational, medical and other needs of members of their community and can better meet them. On the other hand, they need state aid - the provision of financial support to communities through the allocation of funds in the form of subventions from the state budget for the formation of appropriate infrastructure, material incentives for rural doctors, teachers and funds from the State Regional Development Fund.

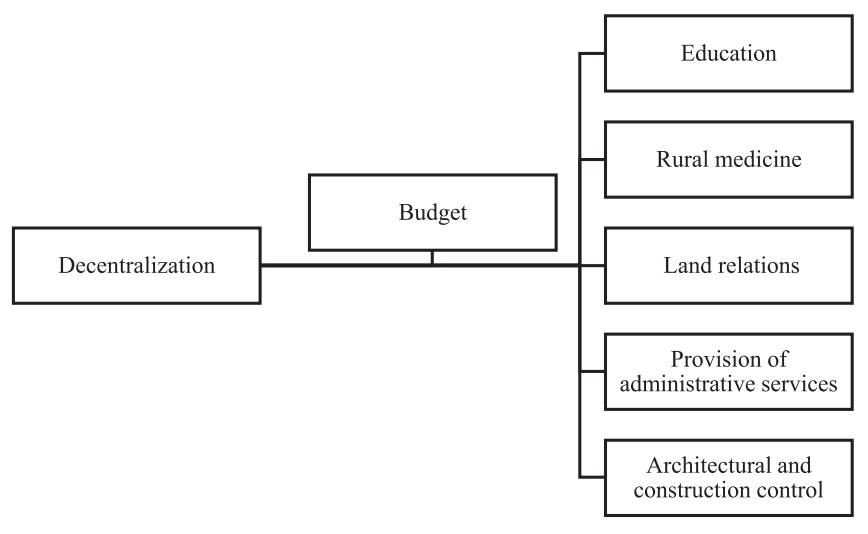

Fig.1. Spheres of decentralization in Ukraine

Since 2014, in accordance with Articles 64, 66 of the Budget Code, income sources of territorial communities have been expanded significantly and consist of $60 \%$ of personal income tax, parts of excise tax, in particular excise tax on retail fuel, alcoholic beverages and tobacco products, ecological tax, rents.

The role of local taxation in formation of capable communities is growing in Ukraine. Budgets of ATCs receive two local taxes, in particular, property tax, which consists of real estate tax other than a land plot, transport tax, land fee and single tax, as well as local fees: parking fee, tourist fee. Local authorities more actively began to use their right to determine, within the limits of legislation, the rates of local taxes and fees.

The openness of budget information of the local government is the key to its effective activities under the control and with the participation of members of territorial administrative unit of the community. The laws of Ukraine clearly indicate the recognition of the basic principles of transparency in Ukraine, in particular publicity, as one of the basic principles of local self-government and publicity and transparency of the budget system. In particular, Art. 7 of the Budget Code of Ukraine noted that "One of the important principles of the functioning of the budget system of Ukraine is informing the public on budget policy, drafting, reviewing, approving, executing the state budget and local budgets, and monitoring the implementation of the state budget and local budgets" [3]. The principle of transparency and openness is also listed among the main conditions for the voluntary association of territorial communities, as stated in the relevant Law of Ukraine.

Funds from local budgets, including financial resources of the ATC, are included in public funds and therefore they are subject to the main provisions of the Law of Ukraine «About openness of the use of public means». It specifies the criteria and standards for informing the public about the subjects and objects of control by the state and the public in the field of public funds. They include the following funds of local budgets: funds of managers and recipients of funds of local budgets, credit resources provided under local guarantees, 
Table 1 shows the system of distribution of tax revenues and the procedure for the formation of incomes of the amalgamated territorial communities in Ukraine.

Table 1. FORMATION OF BUDGET REVENUES OF ATCS IN UKRAINE IN 2019

\begin{tabular}{|c|c|}
\hline STATE TAXES THAT FORM STATE AND LOCAL BUDGETS & REVENUES OF ATCS \\
\hline $\begin{array}{l}\text { Excise tax } \\
\text { Excise tax on retail trade in alcoholic beverages and tobacco products }\end{array}$ & $\begin{array}{l}100 \% \text { (tax rate for beer, alcoholic } \\
\text { beverages, tobacco products, tobacco and } \\
\text { industrial tobacco substitutes sold by } \\
\text { business entities of retail trade of excisable } \\
\text { goods is } 5 \% \text { ) }\end{array}$ \\
\hline $\begin{array}{l}\text { Excise tax on fuel produced in Ukraine and excise tax on goods imported into } \\
\text { the customs territory of Ukraine }\end{array}$ & $\begin{array}{l}13,44 \% \text { of excise tax on fuel produced in } \\
\text { Ukraine and } 13,44 \% \text { of excise tax on goods } \\
\text { imported into the customs territory of } \\
\text { Ukraine are automatically charged to the } \\
\text { budget }\end{array}$ \\
\hline Personal income tax & $60 \%$ \\
\hline \multicolumn{2}{|l|}{ Corporate income tax } \\
\hline Corporate income tax for utility company & $100 \%$ \\
\hline \multicolumn{2}{|l|}{ Ecological tax } \\
\hline Ecological tax (except for the ecological tax on radioactive waste) & $25 \%$ \\
\hline \multicolumn{2}{|l|}{ Rent } \\
\hline Rent on special usage of water & $10 \%$ \\
\hline $\begin{array}{l}\text { Rent on usage of subsoil for the extraction of oil, natural gas and gas } \\
\text { condensate (except for the rent on usage of subsoil within the continental shelf } \\
\text { and /or the exclusive (marine) economic zone of Ukraine) from the extraction of } \\
\text { oil, gas and gas condensate }\end{array}$ & $3 \%$ \\
\hline $\begin{array}{l}\text { Rent on usage of subsoil for the extraction of minerals of local significance; rent } \\
\text { on usage of subsoil for purposes not related to the extraction of minerals; rent } \\
\text { on special usage of water of water objects of local significance; rent on special } \\
\text { usage of forest resources }\end{array}$ & $\begin{array}{l}100 \% \text { (such payments are charged to the } \\
\text { location of the relevant natural resources, } \\
\text { and in relation to water bodies - at the } \\
\text { place of tax registration of the payer of the } \\
\text { rent) }\end{array}$ \\
\hline Local taxes and fees & $100 \%$ \\
\hline $\begin{array}{l}\text { Property tax, which consists of property tax other than a land plot; transport } \\
\text { tax; land fee }\end{array}$ & $100 \%$ \\
\hline Single tax for small businesses & $100 \%$ \\
\hline Fees: parking fee, tourist fee & $100 \%$ \\
\hline
\end{tabular}

Source: Compiled by the authors based on The Budget Code of Ukraine

as well as funds of economic entities of municipal property received by them from their economic activities.

The process of creating the ATC and ensuring its transparency and objectivity is monitored by the Ministry of Finance of Ukraine, the Ministry of Economic Development and Trade of Ukraine, The Ministry of Regional Development, Building and Housing and Communal Services of Ukraine.

The Ministry of Regional Development together withBuilding and Housing and Communal Services of Ukraine is a leader in popularizing the process of creating the ATC and provides the public with qualitative information on the progress of this process. The ministry publishes data on the planned and actual use of funds of ATC for the period 20152019 in the context of all regions of Ukraine on website ${ }^{1}$.

As our analysis shows, nevertheless general information

${ }^{1}$ https://decentralization.gov.ua on the website of the Ministry of Regional Development, Building and Housing and Communal Services on the voluntary association of territorial communities is published quite fully, regularly and constantly updated, the disclosure of information on the functioning of ATCs is characterized by considerable fragmentation and depends on the desire and ability of the management of ATCs. More than half of all ATCs do not provide publicly available information on the revenues and expenditures of the budget, subsidies, subventions and loans. And although sites of ATC have been created and work, they lack financial content. Therefore, any member of the community or ordinary citizen cannot fully obtain financial information or learn about the prospects of the development of a separate ATC.

The achievement of decentralization is the growth of a large number of infrastructure projects where more than 11 million of them have already been implemented. Due to state support 
and local budgets, new schools, kindergartens, dispensaries, stadiums, security centers have appeared in the communities.

Residents of ATCs have the opportunity to actually influence the local authorities, plan the development of their society, receive a new quality of educational, medical, social and administrative services, as a result, significantly reduce corruption.

Due to the state support from the State Regional Development Fund and the constant growth of their own incomes, communities have the opportunity to plan and implement priority projects. If we take the incomes of communities for comparison, we will achieve such results: they amounted to 70 billion UAH in 2014, UAH 234 billion in 2018 and UAH 291 billion was planned for 2019. According to state support, UAH 0.5 billion was allocated to the local level in 2014, UAH 33 billion in 2018. These funds are transferred by state government to the regional level, and at the local levels in accordance with the improved development strategies, priority projects are defined. Thus, we achieve a synergy of the state regional policy and regional development strategies that are adopted locally.

One should note here that some ATCs of Zaporizhzhya region (Veselovskaya and Shirokivska ATCs) are winners in the pilot project "Equal-to-equal», conducted within the working group "Committee of the EU-Ukraine Regions» to support decentralization. It is implemented with the support from the U-LEAD Program with Europe.Under this project Zaporizhzhya region and the communities will cooperate with the European ones.
In September 2018 an international study tour by the representatives from the Shirokovo ATC started as a part of the "Equal-to-equal" initiative in Barleben (Germany). The purpose of the visit is to study the best practices for strengthening the economic and institutional potential of the society. The program of the study visit includes various thematic events and meetings with the representatives of the local government and the business sector.

\section{CONCLUSIONS AND PROSPECTS FOR FURTHER RESEARCH}

To build an effective model of budget management, it is important to ensure continuous and systematic disclosure of information on the accumulation of financial resources of state and local budgets and the direction of their use. Budget transparency provides increased control of community representatives and civil society organizations over the financial and budgetary activities of local governments and contributes to increasing their responsibility for the use of public funds.

The creation of an ATC in Ukraine enhances public attention to the transparency of finances at the level of territorial communities and makes it necessary to make additional efforts by society and researchers on measures and mechanisms that can increase the degree of transparency of local finances, which is not yet sufficient.

\section{REFERENCES:}

1. Monitoring of the process of decentralization of power and the reform of local self-government. URL: https://storage. decentralization.gov.ua/uploads/library/file/378/10.02.2019_ukr.pdf(Accessed 14 March 2019).

2. Reporting of the State Treasury Service of Ukraine. URL: https://www.treasury.gov.ua/ua/file-storage/vikonannyaderzhavnogo-byudzhetu(Accessed 4 March 2019).

3. The Budget Code of Ukraine: Law of Ukraine on July 8, 2010, No. 2456-VI. URL: http: // zakon3.rada.gov.ua/laws/show/275517/ed20150101 (Accessed 4 March 2019).

4. The Tax Code of Ukraine: Law of Ukraine on 02.12.2010, No. 2755-VI. URL: http: // zakon3.rada.gov.ua/laws/show/275517/ed20150101 (Accessed14 March 2019).

5. About openness of the use of public means. The Law of Ukraine on September 30, 2015, No. 183-VIII. URL: https://zakon3. rada.gov.ua/laws/show/183-viii (Accessed 12 March 2019).

6. Open Budget. URL: https://openbudget.gov.ua/local-budget?id = 26400100000 (Accessed 4 March 2019).

7. Cabinet of Ministers of Ukraine (2014), "Concept of the Reform of Local Self-Government and Territorial Organization of Government", available at: https://zakon.rada.gov.ua/laws/show/333-2014-\%D1\%80. (Accessed 21 February 2019).

8. Verkhovna Rada of Ukraine (2015), Law of Ukraine "On Voluntary Association of Territorial Communities", URL: https:// zakon.rada.gov.ua/laws/show/157-19 (Accessed 21 February 2019).

9. Verkhovna Rada of Ukraine (2018), Law of Ukraine "About the State Budget of Ukraine for 2019", URL: https://zakon.rada. gov.ua/laws/show/2629-19(Accessed 1 February 2019).

10. Verkhovna Rada of Ukraine (2014) Law of Ukraine “On Cooperation of Territorial Communities", URL: https://zakon.rada. gov.ua/laws/show/1508-18 (Accessed 21 February 2019).

11. Verkhovna Rada of Ukraine (1997), Law of Ukraine “On Local Self-Government”, URL: https://zakon.rada.gov.ua/laws/ show/280/97-\%D0\%B2\%D1\%80(Accessed 21 March 2019). 


\title{
LESSONS FROM FISCAL DECENTRALIZATION IN UKRAINE
}

\author{
VARNALII ZAKHARII \\ Doctor of Economic Sciences, Professor \\ Taras Shevchenko National University of Kyiv, Ukraine, \\ Honored Worker of Science and Technology of Ukraine, \\ Academician of the Academy of Economic Sciences of Ukraine \\ vzs1955@gmail.com
}

\section{DEMYDENKO LIUDMYLA}

PhD in Economics, Associate Professor, Taras Shevchenko National University of Kyiv, Ukraine ipr.demydenko@gmail.com

\section{NAKONECHNA YULIIA}

PhD in Economics, Associate Professor, Taras Shevchenko National University of Kyiv, Ukraine tematika@ukr.net

\section{MIEDVIEDKOVA NATALIIA}

PhD in Economics, Assistant

Taras Shevchenko National University of Kyiv, Ukraine

nsmedvedkova@gmail.com

KEYWORDS: FISCAL DECENTRALIZATION, LOCAL BUDGETS, AMALGAMATED TERRITORIAL COMMUNITY, LOCAL GOVERNMENTS.

For citation: Varnalii Z., Demydenko L., Nakonechna Y., Miedviedkova N. (2019), Lessons From Fiscal Decentralization In Ukraine, Globalization And Business, №7, pp. 73-78. https://doi.org/10.35945/gb.2019.07.009

\section{SUMMARY}

In order to build an effective model of management of budget funds, it is important to ensure the constant and systematic disclosure of information on the accumulation of financial resources of the state and local budgets and the directions for their use. The first results of the process of fiscal decentralization in Ukraine are considered, which is accompanied by changes in the budget and tax legislation. Specifics of the formation of tax revenues of budgets of joint territorial communities are outlined. The state of disclosure of budget documents by the amalgamated territorial communities is highlighted and the need for coordination of the authorities in this area is indicated.

Understanding citizens) spending processes in the pu- blic sector can significantly increase confidence in state institutions, provide conditions for the implementation of necessary reforms in all-important areas of the country. In the context of the fiscal decentralization reform launched in 2015, the issue of transparency of financial information at the local level in Ukraine is raised, as significant amounts of financial resources are transferred to local budgets. Strengthening the focus on local government action on effective management of budget funds should be a priority for public organizations and political parties. The implementation of the state policy aimed at increasing transparency and openness in the management of financial resources in the public sector will ensure the tangible results in the social and economic spheres that will be obtained by the citizens of the communities. 